\title{
Ewa Kowalska
}

Instytut Pamięci Narodowej

\section{Małoletni więźniowie obozów specjalnych NKWD (1939-1940)}

\begin{abstract}
Abstrakt: Pomimo bogatej literatury, opracowań naukowych i publikacji źródłowych zbrodnia katyńska to wciąż zagadnienie, które kryje w sobie wiele niepodjętych przez badaczy aspektów. Jednym z nich jest los małoletnich więźniów trzech obozów specjalnych NKWD: w Starobielsku, Kozielsku i Ostaszkowie. W artykule spróbowano znaleźć odpowiedzi na podstawowe $\mathrm{w}$ tej kwestii pytania: kim byli chłopcy przebywający $\mathrm{w}$ tych obozach, dlaczego się $\mathrm{w}$ nich znaleźli, jak liczna to była grupa, jaki los ich spotkał.
\end{abstract}

Słowa kluczowe: Katyń, obozy specjalne NKWD, Kozielsk, Starobielsk, Ostaszków, małoletni.

Abstract: Despite the rich literature, scientific studies and source publications, the Katyn Massacre is still an issue that hides many aspects not taken up by researchers. One of them is the fate of juvenile prisoners of three NKVD special camps: at Starobilsk, Kozelsk and Ostashkov. The article tries to answer to the basic questions in this matter: who were the boys staying in these camps, why were they in, how large was the group, and what happened to them?

Key w or ds: Katyn, special NKVD camps, Kozelsk, Starobilsk, Ostashkov, the minors.

Drukiem ukazało się wiele opracowań przybliżających zbrodnię dokonana wiosna 1940 r. przez NKWD na skutek decyzji 5 III 1940 r. Jej ofiarami byli żołnierze, policjanci, przedstawiciele innych służb mundurowych, tysiące osób reprezentujacych polską inteligencję, ponad 40 profesji, powołanych pod broń do obrony ojczyzny jesienią 1939 r. W literaturze naukowej kreślacej los ofiar, opartej na bogatym, ale ciagle niepełnym materiale źródłowym, istnieją wciąż niewyjaśnione „białe plamy”, które nie zostały dotychczas objęte badaniami 
historyków. Do takich tematów należą m.in. małoletni zarejestrowani w trzech obozach specjalnych NKWD: w Starobielsku, Kozielsku i Ostaszkowie ${ }^{1}$. Kim byli chłopcy przebywający w tych obozach, dlaczego się w nich znaleźli, jak liczna to była grupa, jaki los ich spotkał? To tylko kilka pytań, na które należy szukać odpowiedzi.

Korzeni postawy młodzieży w czasie agresji na Polskę we wrześniu 1939 r. trzeba szukać w wychowaniu młodych ludzi wiele lat wcześniej, od czasów zaborów Rzeczypospolitej, kiedy to wszelkie przejawy polskości były tępione w życiu publicznym, w tym w edukacji szkolnej. Przez dziesiątki lat pamięć i zarazem marzenie o wolnej Ojczyźnie trwały przede wszystkim w rodzinach. To rodzina przekazując tradycje walki o niepodległość kraju, stanowiła o wychowaniu kolejnych pokoleń patriotów. Po odzyskaniu wolności niejako namacalnego wymiaru nabierały słowa Jana Zamoyskiego: „Takie będą Rzeczypospolite, jakie ich młodzieży chowanie”. Główny cel wszystkich powstających instytucji, zwłaszcza szkół, stanowiła służba odzyskanej Ojczyźnie. Zawody, których wykonywanie wiązało się z noszeniem munduru, uznawano za szczególnie prestiżowe. Mundur był znakiem specjalnej służby Polsce. Noszenie munduru było honorem. Nie wolno go było splamić, nie tylko w sensie wyglądu, ale też zachowania. Piętnowano wszelkie czyny niegodne: pijackie burdy, brak uczciwości, poniżanie podwładnych, karierowiczostwo. Do godnego zachowania w służbie dla kraju przygotowywały kształcenie i wychowanie. Poświęcić życie w obronie niedawno odzyskanej Ojczyzny to był nie tylko obowiązek, ale też ogromny zaszczyt. Dzieci, chłopcy noszący mundurki szkolne, harcerskie marzyli o założeniu prawdziwego munduru. Jeśli rodzinę np. prostych gospodarzy nie było stać na edukację wszystkich dzieci, starano się „posłać do szkół” choć jedno dziecko. Wybrany chłopiec był niejako inwestycją całej rodziny. Przeznaczony na służbę państwu, stanowił o statusie, pozycji całej rodziny w miejscowym społeczeństwie ${ }^{2}$. „Taka wówczas była atmosfera, jakże pełna patriotycznych uniesień i zachowań... żyły jeszcze pokolenia czynu zbrojnego z lat I wojny światowej, świadkowie euforii z odzyskania niepodległości po 123 latach niewoli, [...] uczestnicy zwycięskiej wojny polsko-bolszewickiej 1920 r." ${ }^{3}$

Radosny, spokojny czas niepodległości, bogaty w wiele działań budujących ojczyznę, trwał niespełna 20 lat. Wybuch wojny spowodował, iż do obrony kraju pospieszyli wszyscy:

\footnotetext{
${ }^{1}$ Artykuł jest wstępną próbą zaprezentowania tematu dotyczącego chłopców do lat 18, o których wzmianki pojawiły się w dokumentach sowieckich oraz wspomnieniach tych, którzy przeżyli czas okupacji. Opracowanie to tylko sygnalizuje jedno z zagadnień zbrodni katyńskiej, wymagające dalszych badań.

${ }^{2}$ Zob. np.: E. Kowalska, Młyny czasu. Jan Boroń od Orzechówki do Starobielska, Warszawa 2014.

${ }^{3}$ Wspomnienie Marii Pawelec-Kosznickiej, w: A. Szybis, Katyń niemy krzyk, Warszawa 2015, s. 32.
} 
tak jak ongiś nasi praojcowie żegnali swych synów spieszących w „wojennej potrzebie" zagrożonej Ojczyźnie, tak i my czyniliśmy podobnie. Kiedyś był to czas zagrożeń ze strony Turków, Tatarów, Wołochów czy Moskwy. Teraz groza wiała ze strony Niemców i... Moskwy... - z całej postaci Ojca emanowała jakaś wewnętrzna siła, jakby pewność siebie... pożegnanie... Był wtedy bardzo chory, miał 39 stopni gorączki. Mój Ojciec powiedział: „obowiązek, Ojczyzna, patriotyzm i ani mu w głowie choroba i to w takiej chwili". Na [babci - E.K.] uwagę, iż najpierw powinien się podleczyć a dopiero później myśleć o wojnie, odparł: „mowy nie ma”. Przecież Polska w niebezpieczeństwie, a on miałby chorować? Absurd. Pojechał i koniec ${ }^{4}$.

Wiele dzieci zapamiętało ostatnie słowa pożegnania: „Bądź dzielna, odważna, pracowita i mądra, tak jak na Polkę przystoi - przypominał. Kiedy wrócę to żebym wtedy mógł stwierdzić, że byłaś córką godną Ojca"5.

W trakcie zmagań nierzadko do ojców dołączali małoletni synowie, zwłaszcza gimnazjaliści i harcerze. Wyruszali do ojców po kilku dniach od wybuchu wojny, aby dostarczyć zmianę bielizny i lepszy prowiant. Chłopcy pragnęli też na miarę swoich sił i umiejętności pomóc w zmaganiach z wrogiem, np. donosić wodę i żywność, a jeśli ojciec służył w policji, w udrażnianiu dróg dla wojska. Niektórzy za namową bliskich spieszyli do ojców, aby uciec przed nacierającymi Niemcami, gdyż ojciec utożsamiany był z poczuciem bezpieczeństwa. Ze wspomnień wynika, iż wszystkie lęki towarzyszące chłopcom podczas samotnych poszukiwań ojców mijały po ich odnalezieniu. „Od tej chwili ustapiły moje obawy i strach... Wojna nabrała nowego oblicza, stała się długo oczekiwana przygodą"6. Przygoda, poczucie bycia bohaterem kończyło się w momencie osaczenia przez wrogów. Walczący, w tym ojcowie z dziećmi, musieli zdecydować o oddaniu broni lub ucieczce. „Czas naglił, trzeba było podjacc bardzo trudną decyzję: uciekać w nieznane, czy zostać? Uciekać, ale dokąd? A co z mundurami? Czy mamy prawo bez rozkazu wyższego dowódcy zdejmować mundury? A co z przysięga jaką składaliśmy Rzeczypospolitej?

Jedni byli za ucieczka, inni przeciw..."7

Niemal wszędzie spotykano polujące na żołnierzy i funkcjonariuszy innych służb mundurowych watahy Ukraińców lub oddziały Armii Czerwonej. Decydujący się poddać, zwłaszcza ci, którzy byli świadkami bestialstwa „najazdu Dzingis Hana" z lat 1919-1920, nierzadko zrywali pagony, obawiając się nieobliczalnego postępowania grup, które mogły ich zatrzymać. Wielu jednak, pomimo obaw, zostawiało je, mówiąc: „honoru nie oddam”. Dziś możemy stwierdzić, iż postępowanie podyktowane miłością Rzeczypospolitej, dochowaniem wierności obowiązkom żołnierskim lub policyjnym, pomimo świadomości

\footnotetext{
${ }^{4}$ Wspomnienia Barbary Koziełł-Poklewskiej Grabczewskiej, w: A. Szybis, op. cit., s. 9-10.

${ }^{5}$ K. Balicka, W Starobielsku martwił się o nas, w: Mój Ojciec, red. M. Jankowski, Kraków 1994, s. 11.

${ }^{6}$ S. Nastarowicz, Byliśmy razem w Ostaszkowie, w: Mój Ojciec..., s. 99.

7 Wspomnienie Katarzyny Poloczek-Wójcik, w: A. Szybis, op. cit., s. 26-27.
} 
zagrożeń, było najwyższej próby. Zatrzymani wraz z ojcami chłopcy, nierzadko płacząc, błagali o pozostawienie ojców przy życiü.

Po rozbrojeniu Polaków wziętych do niewoli następował niełatwy marsz w kierunku większych zgrupowań jeńców ${ }^{9}$. Nierzadko opadający z sił, zwłaszcza ranni niewytrzymujący trudów drogi, byli mordowani. Należy podkreślić, iż wszystkich ciagle okłamywano, że po spisaniu wrócą do domów. Kłamstwo o powrocie do bliskich, który ma rychło nastapić, towarzyszyło zatrzymanym do ostatnich chwil pobytu w obozach ${ }^{10}$. Trzeba dodać, iż w myśl umów międzynarodowych, zawartych w okresie caratu, konwencji haskich z 1899 i 1907 r. oraz konwencji genewskiej z 1929 r., za życie i zdrowie jeńców odpowiadali rząd i dowództwo sił zbrojnych kraju, w którego niewoli się znaleźli. W realiach sowieckich obrońcy Polski zostali przekazani w ręce NKWD, gdyż Związek Radziecki tych umów nie honorował. W świetle prawa międzynarodowego zatrzymani i osadzeni $\mathrm{w}$ obozach polscy żołnierze, funkcjonariusze innych służb mundurowych oraz duchowni i wszystkie osoby cywilne nie byli jeńcami. Nie byli też internowanymi, gdyż zostali zatrzymani na terytorium swojego kraju. Traktowano ich jak wrogów państwa, gdyż Zwiazek Radziecki kierował się klasowym ustawodawstwem karnym, które miało za zadanie ochronę ustroju socjalistycznego kraju robotników i chłopów.

Zgodnie z wytycznymi władz sowieckich jeńcy po dotarciu do obozów rozdzielczych byli kierowani dalej m.in. do trzech obozów specjalnych: w Starobielsku, Kozielsku, Ostaszkowie ${ }^{11}$. Podróż odbywała się z reguły pociagiem $\mathrm{w}$ wagonach towarowych, w których przewożonych dosłownie upychano. $\mathrm{O}$ trudnych warunkach transportu czytamy we wspomnieniach:

Był październik 1939 r. pociąg staną na jednej z setek stacji, nie wywołując już żadnego zainteresowania, nie budząc ze snu zobojętniałych głodem, pragnieniem, dusznością, jednostajnym rytmem przebytych tysięcy kilometrów. Po pewnym jednak czasie zbudził nas hałas, stukanie karabinów w drzwi i głośne krzyki: „Sobirajties k wysiadku!" - szykujcie się do wysiadania. Zaskoczyło to nas po tylodniowym transporcie, poza tym byliśmy tak zniedołężniali, że gdy po kilku minutach otwarto drzwi wagonu, prawie nie ruszaliśmy się; przebywających tak długo bez światła, zaczęło ono silnie razić i powiększać naszą niezdarność. Ale krzyki „bojców” oraz

${ }^{8}$ S. Nastarowicz, op. cit., s. 99.

${ }^{9}$ R. Szewczyk, Mój 1939 rok, Dobopack Digital Publishing (e-book).

10 Janusz Łuksza, Kronika rodzinna, w zbiorach autorki.

${ }^{11}$ Armia Czerwona zatrzymała ok. 250 tys. żołnierzy Wojska Polskiego, funkcjonariuszy Korpusu Ochrony Pogranicza, Straży Granicznej i Policji Państwowej. W celu ,zagospodarowania zdobycznych zasobów ludzkich" jeńcy zostali przekazani organom NKWD. Na mocy rozkazu nr 0308 ludowego komisarza spraw wewnętrznych Ławrientija P. Berii z 19 X 1939 r. utworzono przy NKWD ZSRR Zarząd do Spraw Jeńców Wojennych, którego szefem został major, a od marca 1940 r. kapitan bezpieczeństwa państwowego (b.p.) Piotr Soprunienko. Odpowiadał za obozy jenieckie. Osiem z nich (grazowiecki, juchnowski, jużski, kozielszczański, orański, putywlski, wołogodzki, frydrychowski) było wykorzystywane jako tzw. rozdzielcze, a trzy (kozielski, ostaszkowski, starobielski) otrzymały status obozów specjalnych NKWD. 
nasadzanie bagnetów dla postrachu zmobilizowały silniejszych. Zaczęto powoli zsuwać się na peron, innym trzeba było pomagać, a jeszcze innych po prostu taszczyć... Po oswojeniu się ze światłem zobaczyliśmy, że jesteśmy bardzo bladzi, jakby postarzali, $\mathrm{z}$ pochylonymi plecami, jak po ciężkiej chorobie... ${ }^{12}$

Po dotarciu do stacji docelowych przewożeni szli lub jechali, a w przypadku Ostaszkowa ten ostatni odcinek podróży do obozu specjalnego płynęli na barce. Osiagając cel, wchodzili w kompleksy klasztorne, w których mieli spędzić najbliższe miesiące ${ }^{13}$.

Obozy specjalne mieściły się w murach dawnych monastyrów dostosowanych do przyjęcia jeńców. Adaptacja pomieszczeń do zamieszkania przez wiele tysięcy osób polegała na opróżnieniu znajdujacych się w murach klasztornych magazynów i budowie prycz, nieraz wielopiętrowych. Instrukcja skierowana do administracji obozów zawierała wytyczne dotyczące m.in. izolacji jeńców oraz wewnętrznego reżimu. Przewidywały one, oprócz wysokiego ogrodzenia, utworzenie pięciometrowej strefy bezpieczeństwa - oddzielonej trzema drutami kolczastymi. Ponadto stanowiły m.in. o zasadach przyjmowania jeńców, prowadzeniu przez nich korespondencji, systemie kar, skarg i podań, wykazach przedmiotów, których posiadanie było zabronione, o trybie informowania o przypadkach śmierci i pochówkach ${ }^{14}$. Niejako uzupełniał je, podpisany tego samego dnia - 28 IX 1939 r., regulamin wewnętrzny podany do ogólnej wiadomości. Kreślił on plan dnia oraz ramy czasowe ciszy nocnej obowiązujacej od 23.00. Po tej godzinie opuszczenie budynków przez jeńców groziło zastrzeleniem bez ostrzeżenia ${ }^{15}$.

Zwracajac uwagę na małoletnich, należy uzupełnić, iż ojcowie już w drodze, przez wskazanie na dziecko, przekraczali granicę dzielącą „nieludzką ziemię” od świata wartości ludzkich. Eskortujący żołnierze pozwalali na podanie np. dodatkowych porcji chleba przez osoby znajdujace się na peronach. W obozach przejściowych wartownicy zezwalali ojcom na wymianę np. zegarków czy wiecznych piór na dodatkowe porcje jedzenia dla chłopców. Gdy wreszcie ojcowie wraz z synami dotarli do dawnych monastyrów, wartownicy podczas przymusowej pracy czasem „przymykali oczy” na wymianę przez chłopców drobnych rzeczy np. na jabłka z miejscowymi. Ojcowie dzielili się z synami skapymi racjami żywnościowymi, a synowie starali się zdobyć „rarytasy”,

12 Z. Godlewski, Przeżyłem Starobielsk, „Wojskowy Przegląd Historyczny” 1993, nr 2, s. 308.

${ }_{13}$ Artykuł przybliżając rzeczywistość obozowa, w jakiej przyszło walczyć o przeżycie małoletnim więźniom, w dalszej części nie opisuje poszczególnych obozów oddzielnie, np. różnic w ich lokalizacji i zabudowie, lecz trudne warunki bytowe represjonowanych, dotyczy także kwestii znalezienia się i radzenia sobie z rzeczywistościa obozowa, które to doświadczenia były w znacznej części wspólne, niezależnie od obozu, zdeterminowane wolą przetrwania i nadzieja połaczenia z bliskimi w przyszłości.

${ }^{14}$ Rossijskij Gosudarstwiennyj Wojennyj Archiw (dalej: RGWA), f. 1/p., op. 1a, d. 1, s. 29-45.

${ }^{15}$ Regulamin wewnętrzny obozu NKWD do przetrzymywania jeńców wojennych z 29 IX 1939 r., w: Katyń. Dokumenty zbrodni, t. I: Jeńcy nie wypowiedzianej wojny, sierpień 1939 - marzec 1940, Warszawa 1995, s. 114. 
również do podziału. Wyżywienie było niezwykle skape. Do kotłów z zupą na obiad (niesmaczną breja z jakiś ochłapów, np. nieoczyszczonych ryb) ustawiały się długie kolejki, nie starczało gorącej wody do picia. W miarę upływu czasu głód powodował utratę wagi. Zmiany w wyglądzie były widoczne zwłaszcza u chłopców, którzy rośli. Ich szkolne szynele, spodnie stawały się za krótkie, uwidaczniając chudość kończyn i wzbudzając ogólną litość. „Najtragiczniejszy widok stanowili mali chłopcy, którzy dostali się do Ostaszkowa wraz ze swoimi ojcami, lecz ich los był lepszy w porównaniu z losem kilkudziesięciu chłopców, których zabrano z podmiejskich pociagów Wilna. Ci ostatni przeważnie z teczkami pełnymi książek szkolnych, pozbawieni jakichkolwiek rzeczy, zbierali się w gromadki, aby nie zaginać w tym tłumie, który ich otaczał" 16 .

Do wiecznego odczuwania głodu wkrótce dołączyła plaga wszy i pluskiew. Sprzyjał jej niski stan higieny spowodowany zatłoczeniem pomieszczeń i skutkami powszechnych dolegliwości jelitowo-żołądkowych. Zatrzymani chorowali często na biegunkę, która wycieńczała ich organizmy. Te dolegliwości, wraz z faktem małej ilości wody i mydła, brakiem u wielu jeńców bielizny na zmianę, koniecznością spania w tym samym ubraniu, utrudniały niełatwą codzienność życia obozowego. „Nie otrzymywaliśmy zmiany bielizny ani mydła, a tragedia było otrzymanie wydzielonej wody do mycia. Wodę do kranów podawał hydrofor, który często nie pracował. Z braku napędu zasilania wody ciagle było brak, a w wyznaczonym czasie nie było możliwości umycia się. Z tego powodu skóra pokryta była skorupą brudu, co sprzyjało rozwojowi wszy"17.

W grupie osób śpiących obok siebie wygranie walki z wszami praktycznie było niemożliwe. Jak odnotował dr Zbigniew Godlewski: „Należało się dziwić, że pomimo ogromnego zawszenia nie rozwinął się tyfus plamisty, który jak wiemy, zabierał tysiące istnień ludzkich w czasie wszystkich większych wojen. Tajemnica tego wyjątkowego zjawiska tkwiła chyba w tym, że akurat szczęśliwie nie znalazły się w tym ogromnym zbiorowisku zakażone tyfusem wszy. Może dlatego też, że przestrzegano w Polsce okresu międzywojennego przymusowych szczepień zapobiegawczych...”18

Warunki bytowe były szczególnie trudne w pomieszczeniach o dużej powierzchni, w których mieszkały setki osób. Najlepiej oddaja je wspomnienia tych, którzy przeżyli:

Budynek przy małej cerkwi zwany był cyrkiem... Przy ścianach sali stały rusztowania z pryczami przytwierdzone do muru żelaznymi hakami. Ogromne „rusztowanie”

\footnotetext{
${ }^{16}$ Instytut Polski i Muzeum im. gen. Sikorskiego (dalej: IPMS), Kol. 172/1, s. 11. Obóz specjalny NKWD, powszechnie nazywany ostaszkowskim, położony był na wyspie Stołobnyj, mieścił się w dawnym monastyrze - Pustelni Niłowo-Stołobieńskiej, od stałego lądu oddzielały go wody jeziora Seliger.

${ }^{17}$ Muzeum Katyńskie, Oddział Martyrologiczny Muzeum Wojska Polskiego (dalej: MK), Relacje 690/0.

18 Z. Godlewski, op. cit., s. 318.
} 
sięgało pod sklepienie - na rusztowaniu setki prycz - jak półki wielkiego magazynu. Wewnątrz - jak w ulu, słychać było wieczny szum - czasem krzyki i przekleństwa. Smród stanowił mieszaninę potu, kurzu i braku powietrza. Niektóre prycze były jakby odizolowane wiszącymi rzeczami... Kilku jeńców mieszkało pod sceną w budce suflera....dlaczego pomieszczenie to nazywano „cyrkiem”... Przecież nie było tu nic do śmiechu, raczej groza i smutek. Wydaje się, że to wspinanie się po pryczach, te „izolatki”, śmiechy, śpiewy, wycia - to już nie rzeczywisty świat, lecz coś z prawdziwego cyrku czy teatru ${ }^{19}$.

Gdy nad obozami zawisło widmo wybuchu epidemii, więźniowie, w tym ojcowie wraz z synami, zostali zagnani grupami do łaźni.

[...] po raz pierwszy w życiu jestem razem z Ojcem wśród kilkudziesięciu nagich, dorosłych mężczyzn. Czuję się bardzo skrępowany i pamiętam twarz Ojca, że on bardzo to przeżywał. W życiu nie przypuszczałem, że kiedykolwiek, ja dorastajacy chłopak, znajdę się razem z Ojcem w tak niezręcznej sytuacji. Wyłapujemy wszy, które po oddaniu do dezynfekcji ubrań i bielizny przeniosły się na zawsze na nasza odzież. Po nocach wszy z pluskwami tną niemiłosiernie, swędzi całe ciało, a łapanie tego robactwa jest stałym zajęciem ${ }^{20}$.

Wraz z upływem dni w obozach robiło się coraz chłodniej. Zimno szczególnie odczuwali jeńcy przebywający na wyspie Stołobnyj na jeziorze Seliger. Tu odczucie chłodu pogłębiały wiatry wiejące od jeziora. „Ojciec zrobił mi z koca jednopalcowe rękawiczki, szalik i owijacze na nogi” ${ }^{21}$ - czytamy we wspomnieniach.

Należy dodać, iż na terenie byłego klasztoru Niłowa Pustyń jeńców dodatkowo osłabiał nakaz pracy. Zgodnie z regulaminem Zarządu do Spraw Jeńców Wojennych przetrzymywani pracowali od godz. 8.30 do 16.30. Byli podzieleni na osiem stałych brygad: budowlana, ślusarska, stolarska, krawiecka, szewska, piekarska, dyżurująca w kuchni oraz w pralni i przy dezynfekcji. Oprócz tego jeńcy byli zatrudniani jeszcze przy pracach porządkowych: usuwaniu śmieci, czyszczeniu latryn, wyrównywaniu ziemi w strefie bezpieczeństwa oraz przy budowie i umacnianiu grobli łączącej wyspę z półwyspem Świetlica. Złe warunki bytowe odbijały się na stanie zdrowia jeńców. Wszyscy źle odziani, nieprzygotowani na zimę, zakwaterowani w wilgotnych i zimnych pomieszczeniach klasztornych, głodni, szybko tracili siły. Wielu zapadało, oprócz powszechnych dolegliwości jelitowo-żołądkowych, na gruźlicę, rozmaite powikłania przeziębien, angin, grypy i choroby skóry wynikające z infekcji po zadrapaniach i zranieniach ${ }^{22}$.

19 Por. E. Gruner-Żarnoch, Starobielsk w oczach ocalatych jeńców, Szczecin 2001, s. 162; Z. Godlewski, op. cit., s. 321.

${ }^{20}$ S. Nastarowicz, op. cit., s. 103-104.

${ }^{21}$ Ibidem, s. 105.

${ }^{22} \mathrm{O}$ trudnych warunkach bytowych w obozie ostaszkowskim najlepiej świadczy liczba zmarłych, znacznie przewyższająca szacunki zgonów w dwóch pozostałych obozach specjalnych. 
Do przedstawionych wyżej warunków walki o przetrwanie dochodziła wieczna troska przetrzymywanych o najbliższych pozostających pod okupacją sowiecką lub niemiecka.

\begin{abstract}
Ojciec w komendanturze obozu dowiaduje się, że jestem na liście osób przewidzianych do opuszczenia obozu... Więc mam wracać do kraju? Nie chcę opuścić Ojca, a On mnie długo przekonuje, abym wyjechał najbliższym transportem i zapewnia, że w czasie drogi będę miał opiekę. Do wyjazdów wyznaczono oprócz małoletnich, szeregowych wojska i cywilów, wśród których są znajomi Ojca.

Wiem, że stałą troską Ojca jest brak wiadomości o losach siostry i babci, a to skłoniło Ojca do podjęcia takiej decyzji. W tym czasie bardzo pogorszyły się warunki pogodowe, nadchodziła zima, a my nie mieliśmy ciepłej odzieży...

21 listopada nasz transport opuszcza obóz; z płaczem, uściskami, błogosławieństwem rozstaję się z Ojcem... Jego zrozpaczonej, zatroskanej twarzy nie zapomnę do końca moich dni...23
\end{abstract}

Decyzje ojców były bardzo trudne. Należy pamiętać, iż doświadczyli I wojny światowej i lat 1919-1920. W związku z tym nasuwa się retoryczne pytanie, czy mogli zaufać Sowietom, że dziecko dojedzie do domu, tak jak mówili?

Według danych zebranych na podstawie dokumentów znajdujących się w Wojskowym Biurze Historycznym (dawnym Centralnym Archiwum Wojskowym), Archiwum Instytutu Pamięci Narodowej, Archiwum Instytutu Polskiego i Muzeum im. gen. Sikorskiego, Archiwum Muzeum Katyńskiego Oddziału Martyrologicznego Muzeum Wojska Polskiego, baz elektronicznych uzupełnianych w oparciu także o dane z Urzędu do Spraw Kombatantów i Osób Represjonowanych, Związku Sybiraków udało się ustalić, iż łącznie z trzech obozów specjalnych zwolniono ponad 50 zarejestrowanych chłopców.

Obóz w Starobielsku opuściło 25 zarejestrowanych chłopców w wieku od 10 do 17 lat. Byli to:

- Jan Żpurtacz, syn (s.) Ignacego, urodzony (ur.) 1929 r., zwolniony (z.) 11.10.1939 r.

- Aleksandr Słomiński, s. Zygmunta, ur. 1925 r., z. 20.11 .1939 r.

- Andrzej Ozierski, s. Grzegorza, ur. 1925 r., z. 4.11 .1939 r.

- Andrzej Wojtysiak, s. Józefa, ur. 1925 r., z. 14.10.1939 r.

- Józef Gala, s. Józefa, ur. 1924 r., z. 16.10.1939 r.

- Jan Skarżyński, s. Walentego, ur. 1924 r., z. 4.11.1939 r.

- Stefan Frantczak, s. Stefana, ur. 1924 r., z. 17.10.1939 r.

- Jan Zuch, s. Józefa, ur. 1924 r., z. 16.10.1939 r.

- Bogusław Sobol, s. Lucjana, ur. 1924 r., z. 4.11.1939 r.

- Adam Kapiczenko, s. Piotra, ur. 1923 r., z. 16.10.1939 r.

Zob. Katyń. Księga Cmentarna Polskiego Cmentarza Wojennego, Warszawa 2000; Charków. Ksiega Cmentarna Polskiego Cmentarza Wojennego, Warszawa 2003; Miednoje. Księga Cmentarna, Warszawa 2005.

${ }^{23}$ S. Nastarowicz, op. cit., s. 105-106. 
- Zbigniew Żeżych, s. Rudolfa, ur. 1923 r., z. 17.10.1939 r.

- Mieczysław Kurczab, s. Władysława, ur. 1923 r., z. 16.10.1939 r.

- Wieńczysław Sobalski, s. Jana, ur. 1923 r., z. 24.10.1939 r.

- Franciszek Skupiec, s. Andrzeja, ur. 1923 r., z. 26.10.1939 r.

- Henryk Musiał, s. Stanisława, ur. 1923 r., z. 11.10.1939 r.

- Bolesław Morek, s. Antoniego, ur. 1923 r., z. 11.10.1939 r.

- Kazimierz Bugajski, s. Marcina, ur. 1922 r., z. 16.10.1939 r.

- Tadeusz Brzeźniak, s. Wojciecha, ur. 1922 r., z. 16.10 .1939 r.

- Teodor Boh, s. Franciszka, ur. 1922 r., z. 4.11.1939 r.

- Zdzisław Goliński, s. Władysława, ur. 1922 r., z. 17.10.1939 r.

- Tadeusz Górecki, s. Franciszka, ur. 1922 r., z. 16.10.1939 r.

- Roman Grigorowicz, s. Jakuba, ur. 1922 r., z. 24.10.1939 r.

- Karol Romanowski, s. Karola, ur. 1922 r., z. 11.10.1939 r.

- Gabriel Skupik, s. Wilhelma, ur. 1922 r., 24.10.1939 r.

- Marian Sowa, s. Stefana, ur. 1922 r., z. 11.10.1939 r.

$\mathrm{Z}$ obozu w Kozielsku zwolniono grupę zarejestrowanych 16 chłopców w wieku 16-17 lat. Należeli do niej:

- Szargit Wawreniuk, s. Piotra, ur. 1923 r., z. 14.10.1939 r.

- Kazimierz Chamelo, s. Antoniego, ur. 1922 r., z. 18.10 .1939 r.

- Józef Grad, s. Jana, ur. 1922 r., z. 14.10.1939 r.

- Józef Iwanicki, s. Edwarda, ur. 1922 r., z. 14.10.1939 r.

- Mojsiej Jesilewicz, s. Lazara, ur. 1922 r., z. 14.10.1939 r.

- Jan Lewkowski, s. Aleksandra, ur. 1922 r., z. 14.10.1939 r.

- Wojciech Małko, s. Jakowa, ur. 1922, z. 14.10.1939 r.

- Jerzy Margraf, s. Karola, ur. 1922 r., z. 14.10.1939 r.

- Hieromin Miliszewski, s. Stanisława, ur. 1922 r., z. 14.10 .1939 r.

- Herson Miliszewski, s. Stanisława, ur. 1922 r., z. 18.10.1939 r.

- Zygmunt Woźniak, s. Józefa, ur. 1922 r., z. 14.10.1939 r.

- Leon Przerwa, s. Władysława, ur. 1922 r., z. 14.10 .1939 r.

- Mikołaj Szulejko, s. Józefa, ur. 1922 r., z. 14.10.1929 r.

- Aleksander Szydło, s. Adama, ur. 1922 r., z. 14.10.1939 r.

- Aleksander Szydło, s. Jewdochima, ur. 1922 r., z. 14.10.1939 r.

- Konstanty Untek, s. Ludwika, ur. 1922 r., z. 25.10.1939 r.

Natomiast z obozu w Ostaszkowie z grupy zarejestrowanych 21 chłopców zwolniono 11 małoletnich w wieku od 12 do 17 lat:

- Konstanty Trawczy/e/n, s. Jana, ur. 1927 r., z. 12.10.1939 r.

- Stefan Nastarowicz, s. Michała, ur. 1924 r., z. 25.11.1939 r.

- Henryk Fiedorowicz, s. Jana, ur. 1922 r., z. 12.10.1939 r.

- Henryk Kupisz, s. Jana, ur. 1923 r., z. 20.11.1939 r.

- Jan Gojdysz, s. Jana, ur. 1922 r., z. 20.10.1939 r.

- Alfons Kimcewski, s. Stanisława, ur. 1922 r., z. 12.10 .1939 r. ${ }^{24}$

${ }^{24} \mathrm{~W}$ bazie Indeksu Represjonowanych istnieją dwa zapisy nazwiska: Kimcewski i Kilcewski. 
- Jan Markiewicz, s. Jana, ur. 1922 r., z. 12.10 .1939 r.

- Henryk Muś, s. Romana, ur. 1922 r., z. 20.11.1939 r.

- Michał Romanowski, s. Antoniego, ur. 1922 r., z. 12.10 .1939 r.

- Józef Sosnowski, s. Antoniego, ur. 1922 r., z. 12.10.1939 r.

- Kazimierz Sosnowski, s. Antoniego, ur. 1922 r., z. 12.10.1939 r.

W alfabetycznej kartotece ewidencyjnej jeńców z 1939 r. w obozie ostaszkowskim zarejestrowano 10 chłopców, których los jest nieznany:

- Maciej Zawierug/h/a, s. Jakuba, ur. 1926 r., brak daty zwolnienia i informacji o dalszym losie

- Stefan Górski, s. Teodora, ur. 1925 r., brak daty zwolnienia i informacji o dalszym losie

- Mirosław Kitta, s. Augusta, ur. 1926 r., brak daty zwolnienia i informacji o dalszym losie

- Ryszard Jelecki, s. Mikołaja, ur. 1923 r., brak daty zwolnienia i informacji o dalszym losie

- Andrzej Koterba, s. Józefa, ur. 1923 r., brak daty zwolnienia i informacji o dalszym losie

- Henryk Mańkowski, s. Wacława, ur. 1923 r., brak daty zwolnienia i informacji o dalszym losie

- Mirosław Żenkiewicz, s. Edwarda, ur. 1923 r., brak daty zwolnienia i informacji o dalszym losie

- Włodzimierz Góra, s. Martyna - Marcina, ur. 1922 r., brak daty zwolnienia i informacji o dalszym losie

- Janusz Kopczyński, s. Kazimierza, ur. 1922 r., brak daty zwolnienia i informacji o dalszym losie

- Michał Leszkiewicz, s. Grzegorza, ur. 1922 r., brak daty zwolnienia i informacji o dalszym losie.

Z grupy 16 chłopców, którzy zostali zarejestrowani w Starobielsku, najwięcej informacji mamy o czternastoletnim jedynym synu mjr. Skarżyńskiego. „Ojciec, cień człowieka, wychudzony i chorowity, szalał. Latał od Bierieszkowa do Kirszyna, pisał podania do władz najwyższych sowieckich, do ambasadora amerykańskiego w Moskwie - wszystko to w zamiarze uwolnienia z niewoli nie tylko siebie, lecz syna, który miał bezsporne prawa do obywatelstwa USA. [...] Z chorobliwym uporem wierzył w rychłą interwencję stanów Zjednoczonych. Chłopiec opuścił obóz za zezwoleniem władz w jednej z ostatnich partii zwalnianych szeregowców”25.

${ }^{25}$ Major Skarżyński mieszkał przez długie lata w Stanach Zjednoczonych. Tam przyszedł na świat jego ukochany jedynak. Kilka lat przed wojną przeniósł się do Polski. Dalsze losy chłopca zwolnionego 4 XI 1939 r. nie sa znane. Ojciec po uwolnieniu syna, sprawiając wrażenie obłąkanego, nadal pisał do najwyższych władz sowieckich i ambasady amerykańskiej. Dwa miesiące później został wywieziony z obozu w nieznanym kierunku. Zob. B. Młynarski, W niewoli sowieckiej, Londyn 1974, s. 165-167. Majora Walentego Skarżyńskiego brak w Księdze Cmentarnej jeńców obozu w Starobielsku. Być może we 
Nieco więcej wiadomo także o dalszych losach, po zwolnieniu z obozu w Starobielsku, Karola Romanowskiego. Od 1944 do 1946 r. przebywał on w obozie w Kałudze. Przeżył i w 1946 r. został repatriowany do Polski ${ }^{26}$.

Należy także zauważyć, że choć dotąd nie odnaleziono daty zwolnienia z obozu w Ostaszkowie Ryszarda Jeleckiego, jego odnotowanie w bazie internetowej Indeksu Represjonowanych, w wykazie spraw prowadzonych przez NKWD, sugeruje, że chłopiec został zwolniony z obozu i ponownie aresztowany przez NKWD, po czym ślad po nim zaginął.

Przedstawiona wyżej liczebność małoletnich więźniów Starobielska zapewne nie jest pełna. $\mathrm{O}$ istniejących lukach mówią np. wspomnienia tych, którzy przeżyli. Według dr. Zbigniewa Godlewskiego w obozie w Starobielsku do czasu jego rozładowania przebywał np. szesnastoletni syn Jana Batora. Lekarz wspominał, iż ojca wyjeżdżającego drugim 300-osobowym transportem damoj, czyli na rozstrzelanie, pomimo licznych forteli rozdzielono $\mathrm{z}$ synem.

Zrozpaczony ojciec zgłaszał się do władz z prośbą o zmianę decyzji. Gdy to nie pomogło, ktoś kto był właśnie na liście bieżącego wyjazdu, chciał odstapić chłopcu swoje miejsce. Gdy i na to nie wyrażono zgody, ktoś inny zrezygnował z wyjazdu, a na to miejsce potajemnie podstawiono chłopca. Pamiętam, jak dziękowaliśmy temu rezygnującemu i z jakim napięciem czekaliśmy na wynik tego posunięcia. Sprawdzanie przy bramie udało się. Radość była ogromna. Za chwilę jednak, widocznie podczas następnego sprawdzania, Sowieci rozpoznali chłopca i wprowadzili go zrozpaczonego do obozu z powrotem ${ }^{27}$.

Wiadomo także, iż w Starobielsku przebywał kpt. obs. Czesław Jagodziński wraz z siedmioletnim synem Andrzejem i żona majora, lekarza I.P. Lotn. „[...] chłopak kręcił się między więźniami roznosząc «sacharyn» i wzbudzając nawet u sowietów jakieś uczucia godne człowieka. Pewnego dnia jeden z takich żołnierzy poradził, by nasi opuścili otoczenie obozu, gdyż zostanie przeniesiony i sam wskazał drogę do Polski”28.

Z grupy 16 chłopców, którzy zostali zarejestrowani w Kozielsku, nieco więcej można powiedzieć tylko o Wojciechu Małku. Wiemy, iż musiał być

wspomnieniu jest mowa o mjr. kaw. Skarzyńskim z OZ 2 DOL. Zob. T. Kryska-Karski, Straty korpusu oficerskiego 1939-1945, Londyn 1996 (osoba nie występuje na listach wywozowych NKWD).

${ }^{26}$ Centralne Archiwum Ministerstwa Obrony Federacji Rosyjskiej w Podolsku, zespół (dalej: z.) $361 \mathrm{zpp}$, inwentarz (dalej: inw.) 136666, teczka (dalej: t.) 6; z. $361 \mathrm{zpp}$, inw. 136711, t. 4; z. $361 \mathrm{zpp}$, inw. 136699 , t. 1, t. 2 ; z. $361 \mathrm{zpp}$, inw. 116519 , t. 3 ; z. 361 zpp, inw. 136716 , t. 1. Według bazy Indeksu Karol Romanowski figurujacy w zestawieniu „Wywiezieni do Kaługi” urodził się w 1921 r. w Bydgoszczy.

${ }^{27}$ Z. Godlewski, op. cit., s. 327; zob. też: E Gruner-Żarnoch, op. cit., s. 163.

${ }^{28}$ „W listopadzie 1939 r. dotarła do Polski majorowa, żona lekarza naszego pułku wraz z synkiem kuzyna, Andrzejem”. K.W. Wabersich, Mogłem zginać razem z kolegami, „Biuletyn Katyński” 1994, nr 38, s. 23-25. 
zwolniony z obozu, gdyż opuścił Związek Radziecki z Armią Polską. Zginął we Włoszech w walkach o Bolonię ${ }^{29}$.

Dodatkowo wiadomo, iż w obozie musiał się znajdować Adam Tabaczyński, siedemnastoletni syn Andrzeja i Janiny z Możdżeńskich, słuchacz szkoły kadetów we Lwowie. Został on, zgodnie z rozkazem 5 III 1940 r., zamordowany. Znajduje się na listach wywozowych ofiar zbrodni katyńskiej ${ }^{30}$.

Oprócz 16 wyżej wymienionych, w grupie małoletnich przebywających w obozie w Kozielsku należy uwzględnić innych 9 chłopców, o których dowiadujemy się z pisma wysłanego 16 X 1939 r. przez komendanta obozu w Kozielsku kpt. W. Korolowa do szefa Zarządu Głównego NKWD ZSRR do Spraw Jeńców Wojennych mjr. P. Soprunienki. Zostali oni zatrzymani 19 IX 1939 r. wraz z ojcami, policjantami, na stacji Porubanek pod Wilnem i przewiezieni do obozu specjalnego. Byli to gimnazjaliści i harcerze:

- Romuald Szewczyk, s. Andrzeja, ur. 1924 r. w Białymstoku

- Tadeusz Mydłarz, s. Władysława, ur. 1923 r. w Białymstoku ${ }^{31}$

- Mieczysław Karpiński, s. Władysława, ur. 1922 r. w Białymstoku

- Aleksy Bekker, s. Władysława, ur. 1923 r. w Białymstoku ${ }^{32}$

- Edward Kitlas, s. Stanisława, ur. 1923 r. w Piaskach, powiat wołkowyski, województwo białostockie

- Stanisław Ozimek, s. Jana, ur. 1922 r. w Kalbieszewie, województwo lwowskie ${ }^{33}$

- Władysław Pączyński, s. Władysława, ur. 1923 r. w Wilnie

- Władysław Apoznański, s. Władysława, ur. 1921 r. w Guzowie, województwo warszawskie, zamieszkały w Białymstoku

- Stanisław Gutowski, s. Piotra, ur. 1922 r. w Grajewie, województwo białostockie, zamieszkały w Białymstoku.

W wyżej wspomnianym piśmie kpt Kowolow zwracał się z prośbą o powiadomienie, gdzie chłopcy mają być skierowani: czy do domu jako uchodźcy, czy do obozu ostaszkowskiego wraz z ojcami policjantami. Niejako w uzasadnieniu zapytania dodawał, iż nie posiada jakichkolwiek danych na temat ich aktywnej działalności przeciwko jednostkom Armii Czerwonej. Trzy dni później na blankiecie obozu kozielskiego Piotr Soprunienko ołówkiem zanotował: „Tow. Maklarski. Proszę dać polecenie odesłania ich do domu. P. Soprunienko 19 X1939.”34

${ }^{29}$ Wykaz polegtych i zmartych żotnierzy Polskich Sit Zbrojnych na obczyźnie $w$ latach 1939-1946, Londyn 1952, s. 218.

${ }^{30}$ Katyń. Księga Cmentarna..., s. 641.

${ }^{31}$ Brzmienie nazwiska jako prawidłowe - Mydlarz - koryguje relacja Krystyny Potrzebowskiej, MK, 3382/R. Pod nazwiskiem Mydlarz figuruje on także w Wykazie polegtych i zmartych żotnierzy Polskich Sit Zbrojnych na Obczyźnie w latach 1939-1946, Londyn 1952, s. 118.

${ }^{32}$ Imię Aleksy podawane w dokumencie, winno brzmieć Alojzy. IPMS, Kol. 138.164.b.

${ }^{33} \mathrm{~W}$ dokumencie powinno być miejsce urodzenia Kolbuszowa.

${ }^{34}$ Katyń. Dokumenty zbrodni, t. II: Zagłada: marzec-czerwiec 1940, Warszawa 1998, s. 198. 
Ze złożonych przez członków rodzin relacji oraz dokumentów sowieckich wiadomo o dalszym losie siedmiu spośród wyżej wymienionych:

- Romuald Szewczyk został zwolniony z obozu i wrócił do domu ${ }^{35}$.

- Tadeusz Mydlasz został zwolniony i widnieje odnotowany, jako jedyne dziecko, przez Jędrzeja Tucholskiego na liście z Juchnowa i Griazowca ${ }^{36}$. Zdołał on dotrzeć do tworzacej się w 1941 r. Armii Polskiej pod dowództwem gen. Andersa. Jako polski żołnierz zmarł 22 II 1942 r. w Dżalalabadzie ${ }^{37}$.

- Mieczysław Karpiński został rozdzielony z ojcem i przeniesiony do obozu w Juchnowie. Stamtąd 18 VI 1940 r. przetransportowano go do obozu w Griazowcu. Ostatnie wzmianki o nim w dokumentach sowieckich pochodza z Tockoje, stacji Kolei Orenburskiej, gdzie był widziany 3 IX $1941 \mathrm{r} .{ }^{38}$ Informacje odnotowane w dokumentach sowieckich dopełniają zeznania siostry Wandy Karpińskiej z 1943 r. Według nich jej brat Mieczysław wstapił do Armii Polskiej i szczęśliwie został ewakuowany z Rosji sowieckiej ${ }^{39}$.

- Alojzy Bekker został zwolniony w październiku 1939 r. z obozu kozielskiego i powrócił do domu w Białymstoku. Celem powiadomienia o losie kolegów, z którymi został aresztowany na stacji kolejowej Porubanki pod Wilnem, odwiedzal ich rodziny ${ }^{40}$.

- Edward Kitlas został zwolniony z obozu i powrócił do domu. W 1940 r. deportowano go do Kazachstanu ${ }^{41}$.

- Stanisław Gutowski wraz z ojcem przebywał w Ostaszkowie. Według wspomnień siostry Reginy Kowerko został zwolniony z obozu i „w październiku wrócił do Białegostoku. Kontynuował naukę w swoim gimnazjum. Dnia 24 XII 1939 r. został aresztowany przez NKWD i ślad po nim zaginą”"

${ }^{35}$ R. Szewczyk, op. cit.

36 J. Tucholski, Mord w Katyniu. Kozielsk. Ostaszków. Starobielsk. Lista ofiar, Warszawa 1991 s. 536.

${ }^{37}$ Wykaz polegtych $i$ zmartych $\dot{z}$ otnierzy..., s. 118.

${ }^{38}$ Katyń. Dokumenty zbrodni..., t. I, s. 114.

39 J. Tucholski, op. cit. Siostra Mieczysława, Wanda Karpińska, deportowana 13 IV 1940 r. w głąb Rosji, zdołała ją opuścić dzięki ewakuacji rodzin żołnierzy Armii Polskiej. W zeznaniach z 12 II 1943 r. oświadczyła, iż w październiku 1939 r. przyszedł do jej domu harcerz Alojzy Bekker, zatrzymany przez Rosjan na stacji Porubanek pod Wilnem wraz z jej bratem oraz ojcem Władysławem, starszym posterunkowym policji z Białegostoku. Harcerz został zwolniony z Kozielska ze względu na młody wiek, a w obozie pozostali jej bliscy oraz wielu polskich żołnierzy i oficerów. W lutym 1940 r. otrzymała list z obozu w Ostaszkowie, w którym ojciec pisał, że przebywa tam wraz z synem. Z późniejszej korespondencji od brata, po jego wstapieniu do polskiego wojska, dowiedziała się, iż zostali oni rozdzieleni. Ojca wywieziono z obozu i nie wie, gdzie się znajduje. IPMS, Kol. 138.164.b.

${ }^{40}$ Ibidem, zeznanie Wandy Karpińskiej,

${ }^{41}$ Figuruje w bazie internetowej Indeksu Represjonowanych.

${ }^{42}$ MK, 2196/R. Nieco więcej informacji o dalszych losach Stanisława Gutowskiego, s. Piotra i Zofii, ur. 9 VI 1922 r. w Grajewie w województwie białostockim, mówią dwie ankiety znajdujące się w Archiwum Instytutu Pamięci Narodowej. Informuja, iż był on więziony 
- Stanisław Ozimek został zatrzymany wraz z ojcem na stacji kolejowej pod Wilnem. Początkowo przebywał w Kozielsku, po czym razem zostali przeniesieni do Ostaszkowa. Do rodziny dotarła kartka wysłana przez nich z obozu w Ostaszkowie. Przed rozładowaniem obozu ojciec z synem zostali rozdzieleni. Jako pierwszy wyjechał ojciec, syn zaś w jednym z kolejnych transportów. Obaj spoczywają na cmentarzu w Miednoje ${ }^{43}$. O wspólnym pobycie w ojca i brata w dawnej Pustelni Niłowo-Stołobieńskiej mówi relacja p. Heleny Mazurkiewicz z d. Ozimek, która bardzo długo ich poszukiwała ${ }^{44}$.

Relacje p. Reginy Kowerko, p. Heleny Mazurkiewicz oraz zeznanie p. Wandy Karpińskiej sugeruja, iż część wymienionych w piśmie mjr. Kowalowa chłopców przebywających w obozie w Kozielsku została z niego zwolniona, a część przewieziona wraz z ojcami policjantami do obozu w Ostaszkowie. Z obozu na wyspie Stołobnaja niektórych z nich zwolniono lub zamordowano zgodnie z decyzją z 5 III 1940 r. Należy podkreślić, iż chłopcy, którzy po zwolnieniu z obozów trafili do rodzin pod okupacją sowiecka, wkrótce podlegali kolejnym aresztowaniom i represjom. Ustalenie ich losów wymaga dalszych badań archiwalnych ${ }^{45}$.

Oprócz wyżej wymienionych w grupie małoletnich przebywających w obozie w Ostaszkowie należy uwzględnić ośmioletniego syna Feliksa Mastalerza. Dowiadujemy się o nim z pisma komendanta obozu ostaszkowskiego mjr. P. Borisowca do szefa Zarządu do Spraw Jeńców Wojennych kpt. b.p. P. Soprunienki z 15 IV 1940 r. Chłopiec „w chwili obecnej umieszczony został w ostaszkowskim domu dziecka, gdzie się uczy. Jak postapić z synem, w przypadku otrzymania zlecenia na wysłanie jeńca wojennego Mastolasza" ${ }^{\prime 6}$. Dotąd nie udało się odnaleźć dokumentów pozwalajacych ustalić dalsze losy chłopca.

Powyższa próba przybliżenia losów 65 chłopców, którzy w świetle wspomnień i dokumentów sowieckich trafili do obozów specjalnych, wymaga dalszych, pogłębionych badań. Trudno z całą pewnością orzec, ile dokładnie osób małoletnich było w trzech obozach specjalnych NKWD, ilu chłopców zwolniono, ilu z nich dotarło do domów rodzinnych i ilu z grona zwolnionych

w Łagrze w obwodzie archangielskim. Według jednej - tam zmarł, według drugiej - zaginą; figuruje w internetowej bazie spraw prowadzonych przez NKWD.

${ }^{43}$ MK, 4751/R.

${ }^{44}$ Helena Mazurkiewicz wspominała, że Staś był uczniem Liceum Ogólnokształcącego w Oszmianie. Posiadał ponadprzeciętne zdolności w zakresie nauk ścisłych, zwłaszcza matematyki. Jak sięgała pamięcia, pomagał zawsze ojcu, który nie był najlepszego zdrowia, oraz rodzinie. Jego pomoc miała wymiar także materialny, gdyż udzielał korepetycji młodszym i mniej zdolnym uczniom. „Wspomnienia matki”, relacja córki Krystyny Mazurkiewicz, w zbiorach autorki.

${ }^{45}$ Podjęte wobec chłopców działania NKWD zdają się sugerować celowość pozbywania się świadków pobytu wielu tysięcy obywateli polskich w obozach specjalnych NKWD, co powinno znaleźć odzwierciedlenie w dokumentach.

${ }^{46}$ Katyń. Dokumenty zbrodni..., t. II, s. 197. 
wkrótce zostało zamordowanych lub zmarło w wyniku ponownych represji oraz ilu zgładzono w obozach specjalnych?

Należy dodać, iż w artykule nie zostały uwzględnione losy chłopców przebywajacych w obozie, urodzonych po $1921 \mathrm{r}$., obecnie kwalifikowanych jako pełnoletni. Z dokumentów sowieckich i wspomnień rodzin wiemy, iż grono to nie było małe. We wspomnieniach kmdr. Stanisława Dzienisiewicza o kmdr. inż. Kamińskim, który przebywał w obozie w Kozielsku wraz z synem, czytamy: „[...] gdy mu kazano «sobieratsa $\mathrm{z}$ wieszczami» pobiegł zdenerwowany do Zarubina z prośba, ażeby pozwolił mu jechać razem z synem. Nie przypominam sobie czy co wskórał, ale obaj trafili do Katynia" ${ }^{47}$. Zachował się wstrzasający zapis wspomnień szefa NKWD w Kalininie Dmitra Tokariewa, przedstawiający spostrzeżenia oprawców z ostatnich chwil życia młodocianych ofiar: „[...] był bez nakrycia głowy. Wszedł i uśmiechał się, tak, chłopiec, zupełny chłopiec" 48 .

Wstępne badania nad małoletnimi więźniami obozów specjalnych zmuszaja do refleksji nad tym, jak wiele jeszcze nie wiemy o Polakach zatrzymanych w 1939 r. i osadzonych w obozach specjalnych NKWD w Starobielsku, Kozielsku i Ostaszkowie. Ciagle otwarte pozostaja pytania: kim byli represjonowani, zmarli i zamordowani? Do myśli Floriana Znanieckiego, iż należy w nich widzieć „duchowych ojców narodu”, można dopowiedzieć: oraz ich bliskich. Cień obozów padł na losy chłopców, którzy je przeżyli, oraz na rodziny osób zgładzonych na podstawie decyzji z 5 III 1940 r. Wiadomo, iż Stanisław Gutowski, któremu udało się powrócić do bliskich w Białymstoku, został aresztowany przez NKWD 24 XII 1939 r. i ślad po nim zaginął. Czy jego losy można uznać za reprezentatywne dla wszystkich chłopców, którzy powrócili do rodzin na polskich Kresach Wschodnich pod okupacją sowiecką? Czy była to realizacja zamysłu likwidacji świadków zgrupowania i później zagłady inteligencji polskiej $\mathrm{w}$ obozach specjalnych pod zarządem NKWD? Wiemy, jaki los spotkał rodziny ofiar. Zostały one przymusowo wywiezione

${ }^{47}$ S. Dzienisiewicz, Kozielsk, przedpiekle Katynia, w: Ostatnia wachta - Mokrany, Katyń, Charków..., red. J. Przybylski, Gdynia 2000, s. 53-54. Należy dodać, iż w opracowaniu Katyń. Księa Cmentarna... (s. 246) odnotowany jest kmdr por. Stanisław Kamieński, inżynier mechanik morski ze specjalnością łodzi podwodnych. Uczestnik I wojny światowej. Od 1919 w WP. Wieloletni wykładowca w oficerskiej szkole Marynarki Wojennej. Zgodnie ze wspomnieniem Dzienisiewicza przebywał prawdopodobnie w obozie $\mathrm{z}$ jedynym synem Stanisławem, ur. 30 X 1919 r. Brak jednak w opracowaniu odnotowania śmierci syna.

48 Protokół z przesłuchania D. Tokariewa. Katyń. Dokumenty zbrodni..., t. II, s. 452, 469; „Zeszyty Katyńskie” 1994, nr 3. Dmitrij Stiepanowicz Tokariew - od 1927 r. członek Wszechzwiązkowej Komunistycznej Partii (bolszewików) [WKP(b)], pracował w sowieckich służbach specjalnych, był etatowym funkcjonariuszem Zjednoczonego Państwowego Zarządu Politycznego (Objedinionnoje gosudarstwiennoje politiczeskoje uprawlenije - OGPU), NKWD i Ludowego Komisariatu Bezpieczeństwa Państwowego. W 1945 r. nadano mu stopień generała majora. Jako jeden z wykonawców zbrodni na mocy decyzji z 5 III 1940 r., zeznawał w 1991 r. jako świadek w śledztwie. Dwa lata później zmarł w Moskwie w wieku 91 lat. 
w czterech masowych falach deportacyjnych w głąb Związu Radzieckiego, na daleka północ i do Kazachstanu ${ }^{49}$. Dopiero na skutek zmiany sytuacji na arenie międzynarodowej ich los mógł się odmienić. Ci, którzy przetrwali, mogli opuścić sowiecką ziemię razem z Armią Polską pod dowództwem gen. Władysława Andersa, później z polskim wojskiem pod dowództwem gen. Zygmunta Berlinga lub po ustaniu działań wojennych w wyniku repatriacji wrócić do nowej Ojczyzny. Taki los był udziałem wspomnianego Stanisława Gutowskiego. Jego matka wraz z pięciorgiem jego rodzeństwa została w kwietniu 1940 r. wywieziona do Kazachstanu. Udało się im przeżyć i powrócić do kraju w maju 1946 r. ${ }^{50}$ Tak wiele szczęścia nie miały jednak wszystkie deportowane rodziny. Wiele osób nigdy do kraju nie powróciło. Przykładem przebytej przez nich drogi moga być przeżycia bliskich Stasia Ozimka, zgładzonego w Kalininie. Z pięciorga deportowanych 13 IV 1940 r. do Kazachstanu, do kraju w 1946 r. udało się powrócić trzem członkom rodziny ${ }^{51}$.

Dla tych, którzy przeżyli, represje sowieckie lat II wojny światowej nie skończyły się w momencie powrotu do nowej Polski. Przez długie lata pozbawiano ich możliwości głośnego wyznania prawdy. Nie tylko nie mogli pożegnać swoich bliskich, ale musieli godzić się na publiczne zakłamywanie losów swoich oraz represjonowanych, zmarłych i zamordowanych członków rodziny.

Dla wielu znalezienie się w obozie lub specposiołku (osiedlu specjalnym) przez długie lata było źródłem pamięci przeżyć, pamięci traumatycznej. Jak wspominali, doświadczenia z przeszłości nierzadko wpływały na ich powojenne myślenie i działanie ${ }^{52}$. Zaobserwowane przez nich, nawet po latach, lekkie zaciśnięcie szczęk, znieruchomiałe spojrzenie, zmarszczenie brwi odbierali jako zapowiedź przemocy, jeśli nawet nie fizycznej, to psychicznej.

Dziś wiemy, że jednym z przejawów traumy sa powracające obrazy przeżytych okropności, co wpisuje się w syndrom stresu pourazowego. My, którzy nie mieliśmy takich doświadczeń, uznajemy takie zachowanie za przesadne. Dla tych, którzy przeżyli obozy specjalne, gułag czy zesłanie w głąb ZSRR

${ }^{49}$ Rodziny ofiar szeroko rozumianej zbrodni katyńskiej stanowiły najliczniejszą grupę zesłanych w kwietniu 1940 r. do Kazachstanu. Można je jednak spotkać w każdej z czterech masowych fal deportacji z Kresów Wschodnich. Jako pierwsze zostały przymusowo przesiedlone rodziny osadników i leśników w lutym 1940 r. Te rodziny, których członków nie zastano pod adresami wskazanymi na listach proskrypcyjnych w lutym i kwietniu, po dodatkowych ustaleniach przez NKWD, były deportowane w czerwcu 1940 i 1941 r. Zob. E. Kowalska, Przeżyć, aby wrócić! Polscy zestańcy lat 1940-1941 w ZSRR i ich losy do 1946, Warszawa 1998; Spis rodzin wojskowych wywiezionych do ZSRR, wstęp, komentarz historyczny, oprac. aneksów, tabel i map E. Kowalska, Warszawa-Kraków 2014.

${ }^{50}$ MK, 2196/R.

${ }^{51}$ MK, 4750/R.

${ }^{52}$ Kiedy ma się za sobą tego rodzaju przeżycie, w mózgu powstaje nowy obwód pamięci. Stajemy się niezwykle wrażliwi na określony typ informacji, które odtąd postrzegamy z większą ostrością niż inne. Dzieje się to poza naszą świadomością. Zob. Z. Bogumił, Pamięć Gułagu, Kraków 2012. 
ślad pamięciowy wyostrza zdarzenia. Ponieważ groziło im niebezpieczeństwo, łatwiej utożsamiają je z zagrożeniem, „są też bardziej podatni na zranienie”53.

Polskich jeńców zatrzymanych przez Armię Czerwoną i przekazanych w ręce NKWD, aresztowanych, w tym małoletnich, którzy wiele przeżyli, przez dziesiątki lat zmuszano do zachowania milczenia ${ }^{54}$. Przez lata byli niejako więźniami przeszłości. Szczerze mogli rozmawiać tylko między soba, z tymi, których przeżycia były podobne. Zbliżeniu, wzajemnemu zrozumieniu, sprzyjały nie tylko ich stan wewnętrzny, ale też kondycja fizyczna przypominająca o przymusowym pobycie w Rosji sowieckiej. Więźniowie obozów specjalnych po powrocie często cierpieli na rozmaite kalectwa i bolesne dolegliwości, np. kłopoty żołądkowe, owrzodzenia jelitowe.

Izolacja wewnętrzna i zewnętrzna w czasie wojny, wymuszona rozmaitymi okolicznościami, także po wojnie sprawiła, że ci, co przetrwali, nadal odczuwali opuszczenie. Widzieli świat na zewnątrz jak przez szybę i nie brali w jego życiu pełnego udziału. Nierzadko doświadczali niejako ponownego „traumatycznego uwięzienia" i nadal żyli w rozpaczy. Wracały do nich obrazy z przeszłości. Ci, którzy w czasie wojny byli chłopcami, później w snach widzieli zrozpaczone twarze ojców, których zostawiali w obozach. Często wielu działań i osób się bali, pogrążali się depresji. Pamięć kładła się cieniem na teraźniejszości. Czasem spotykajace ich niepowodzenia odczuwali jako potwierdzenie własnej niższości. Zaczynali myśleć, że oprawcy mieli rację, że nimi gardzili, a nawet chcieli zabić. Czasu na powrót do normalności potrzebowano dużo, gdyż po ich przyjeździe do kraju nikt się nie zastanawiał nad ich swoistym odsunięciem, zamknięciem ${ }^{55}$. Nowa Polska nierzadko pozbawiła ich także majątku i godności inteligenckiej rodziny. W powojennej rzeczywistości stali się warstwa

${ }^{53}$ Zob. E. Jackowska, Deportacje na Sybir - psychiczne ślady cierpienia, „Zesłaniec” 2008, nr 34.

${ }^{54}$ Należy dodać, iż ofiary urazów mają rozwinięta pamięć obrazów, a słabą słów. Ważnym czynnikiem ochronnym jest dla nich werbalizacja przeżyć. Słowa to niejako narzędzie emocjonalnej regulacji. Dzięki słowom można się dzielić światem wewnętrznym i mieć dostęp do tego, co myślą inni. Znalezienie słuchacza i głośne wyznanie prawdy ułatwia zapanowanie nad emocjami, tzw. odwentylowanie. Umiejętność stworzenia reprezentacji werbalnej tego, co nas spotkało, i znalezienie adresata naszej opowieści ułatwia panowanie nad emocjami. Możliwość opowiedzenia o przeżyciach stwarza podstawy poczucia bezpieczeństwa, które nie pozwala, aby pamięć wizualna zawładnęła psychika, zalewając ją straszliwymi obrazami.

${ }^{55} \mathrm{Nad}$ przeżyciami, kondycją tych, którzy przeżyli represje sowieckie, nie prowadzono pogłębionych badań dotyczących następstw traumy wojennej. Przez analogię do poddanych analizie przeżyć więźniów obozów koncentracyjnych pod okupacją niemiecką można wnioskować, iż ich postawa wobec nowej rzeczywistości, po tym, czego doświadczyli w Rosji sowieckiej, jest prawdziwym zwycięstwem pod okupantami. Zob. A. Szymusik, Astemia poobozowa u bytych więźniów obozu koncentracyjnego w Oświęcimiu, „Przegląd Lekarski” 1964, nr 1, s. 29-20; M. Orwid, Uwagi o przystosowaniu do życia poobozowego u bytych więźniów obozu koncentracyjnego w Oświęcimiu, „Przegląd Lekarski” 1962, nr 1, s. 94-97; Poobozowe zmiany osobowości bytych więźniów obozu koncentracyjnego Oświęcim-Brzezinka, „Przegląd Lekarski” 1965, nr 1, s. 13-20. 
drugiej kategorii, której nierzadko utrudniano dostęp do kształcenia i pracy zgodnej z poziomem wiedzy i kompetencji. Potrzeba było wielu lat, ażeby na nowo nauczyli się żyć, przyjmować to, co dobre.

Najtrafniejszym podsumowaniem podjętego tematu o trudnych losach dzieci, które doświadczyły represji Rosji sowieckiej, sa pozbawione patosu słowa ich samych: „Zawsze przy podejmowaniu ważniejszych decyzji próbowałem odpowiedzieć sobie na pytanie: co zrobiłby w tej sytuacji mój Ojciec? Jakby się zachował? Ale pamięć o Ojcu w mojej drodze życiowej była nie tylko drogowskazem, lecz także piorunochronem, trzymała mnie w ryzach, wzmacniała moralny kręgosłup, pomagała przezwyciężyć słabości, dodawała energii w walce z przeciwnościami” ${ }^{56}$.

Te słowa skłaniają także do refleksji nad waga pamięci i wychowania, dzięki któremu Polska miała w swojej historii pokolenie małoletnich osób potrafiących „zachować się jak trzeba” zarówno w latach wojny, jak i późniejszych. „[...] wypełniłam Jego wolę: byłam dzielna, odważna, pracowita, tak jak na Polkę przystało, kochałam tę Ojczyznę, w której się urodziłam, wychowałam i dla której narażałam życie" ${ }^{57}$ - czytamy we wspomnieniach.

\section{Streszczenie}

Obraz zagłady obywateli II RP pod okupacją sowiecką jest dość bogaty. Drukiem ukazało się wiele wspomnień, opracowań historycznych oraz edycji źródeł. Pomimo tych publikacji nadal jednak wiele zagadnień pozostaje nieobjętych badaniami historyków. Należą do nich m.in. rozmaite aspekty szeroko rozumianej zbrodni katyńskiej. Stanowi ona symbol represji oraz zagłady obywateli polskich, którzy zostali zatrzymani przez Armię Czerwoną we wrześniu 1939 r., a następnie byli przekazani w ręce NKWD i trafili do obozów w Kozielsku, Starobielsku i Ostaszkowie oraz więzień na tzw. Zachodniej Ukrainie oraz Zachodniej Białorusi. Jednym $z$ aspektów tematu, czekających na opracowanie, jest los małoletnich chłopców, którzy z rozmaitych przyczyn znaleźli się w tych trzech obozach specjalnych NKWD.

Niestety na skutek relacji międzynarodowych ci, którzy przeżyli czas represji sowieckich, przez dziesiątki lat byli zmuszeni milczeć o przeżyciach swoich oraz swych bliskich podczas pobytu w Rosji sowieckiej. Odchodzac, wiele informacji zabrali ze sobą na zawsze. Obecnie o ich trudnej drodze można wnioskować jedynie na podstawie, nadal dostępnych tylko w części, dokumentów wytworzonych przez władze sowieckie, wspomnień tych, którzy przeżyli obozy, oraz relacji złożonych przez ich bliskich. Pozwalają one na wstępne określenie: kim byli chłopcy przebywający w tych obozach, dlaczego się w nich znaleźli, jak liczna to była grupa oraz jaki los ich spotkał. Należy podkreślić, iż artykuł tylko sygnalizuje zagadnienie wymagające podjęcia dalszych badań. Poza względami faktograficznymi jest on podstawa refleksji nad mechanizmami zbrodni i milczenia na arenie międzynarodowej, a także rozważań nad wychowaniem w rodzinach, które stanowiły o zachowaniu polskości społeczeństwa, kształtowały wartości moralne swoich członków, nawet podczas najcięższych prób.

${ }^{56}$ Krzysztof Studnicki, w: A. Szybis, op. cit., s. 18.

${ }^{57}$ K. Balicka, op. cit., s. 15. 


\section{Underage Prisoners of NKVD Special Camps (1939-1940)}

The picture of the extermination of citizens of the Second Polish Republic under Soviet occupation is quite rich. Many memories, historical studies and edition of source materials appeared in print. Despite these publications, however, a large number of issues remain outside the scope of historical research. These include various aspects of the broadly understood Katyn Massacre. It is a symbol of the repression and extermination of Polish citizens detained by the Red Army in September 1939, and then transferred to the NKVD and sent to the camps at Kozelsk, Starobilsk and Ostashkov, and prisons on the so-called Western Ukraine and Western Belarus. One aspect of this theme that awaits further study is the fate of underage boys who found themselves in these three NKVD special camps for various reasons.

Unfortunately, as a result of international relations, those who survived the period of Soviet repression, for decades were forced to remain silent about what they personally and their loved ones' experienced during their stay in Soviet Russia. Passing out, they took a lot of information with them forever. At present, their difficult path can be reconstructed only on the basis of documents, still only partially available, produced by the Soviet authorities, memories of those who survived the camps, and accounts submitted by their relatives. They allow for an initial establishment of some facts: who were the boys staying in these camps, why were they in them, how large was the group, and what happened to them. It should be emphasised that the article only indicates the fields for further research. In addition to some facts, it forms the basis for reflection on the mechanisms of crime and silence on the international arena, as well as on upbringing in families which made it possible to preserve Polishness of the society, shaped the moral values of their members, even during the most difficult times.

\section{Bibliografia}

Bogumił Z., Pamięć Gułagu, Kraków 2012.

Charków. Księga Cmentarna Polskiego Cmentarza Wojennego, Warszawa 2003.

Gruner-Żarnoch E., Starobielsk w oczach ocalałych jeńców, Szczecin 2001.

Katyń. Księa Cmentarna Polskiego Cmentarza Wojennego w Katyniu, Warszawa 2000.

Kowalska E., Mtyny czasu. Jan Boroń od Orzechówki do Starobielska, Warszawa 2014.

Kowalska E., Przeżyć aby wrócić! Polscy zestańcy lat 1940-1941 w ZSRR i ich losy do roku 1946, Warszawa 1998.

Kryska-Karski T., Straty korpusu oficerskiego 1939-1945, Londyn 1996.

Miednoje. Ksiega Cmentarna, Warszawa 2005.

Młynarski B., W niewoli sowieckiej, Londyn 1974.

Mój Ojciec, red. M. Jankowski, Kraków 1994.

Ostatnia wachta - Mokrany, Katyń, Charków..., red. J. Przybylski, Gdynia 2000.

Spis rodzin wojskowych wywiezionych do ZSRR, wstęp, komentarz historyczny, oprac. aneksów, tabel i map E. Kowalska, Warszawa-Kraków 2014.

Szybis A., Katyń niemy krzyk, Warszawa 2015.

Tucholski J., Mord w Katyniu. Kozielsk. Ostaszków. Starobielsk. Lista ofiar, Warszawa 1991. Wykaz polegtych i zmartych żotnierzy Polskich Sit Zbrojnych na obczyźnie w latach 1939-1946, Londyn 1952. 
Biog r a m: Ewa Kowalska - doktor nauk humanistycznych w zakresie historii, pracownik Biura Poszukiwań i Identyfikacji IPN. W centrum jej zainteresowań są zagadnienia losów ludności polskiej okresu międzywojennego i czasów II wojny światowej. Autorka wielu artykułów i prac poświęconych trudnym doświadczeniom Polaków, m.in.: Admirat z Pałuk. Józef Unrug (wraz z Agnieszką Cieślik; 2001); Przeżyć, aby wrócić! Polscy zesłańcy lat 1940-1941 w ZSRR $i$ ich losy do roku 1946 (1998); Mtyny czasu. Jan Boroń od Orzechówki do Starobielska (2014); Spis rodzin wojskowych wywiezionych do ZSRR (2014). E-mail: ewa.kowalska@ipn.gov.pl. 